\title{
Massive thrombus trapped within an atrial septal defect
}

\author{
Dominika M Zoltowska, ${ }^{1}$ Yashwant Agrawal, ${ }^{2}$ Vishal Gupta, ${ }^{3}$ \\ Jagadeesh K Kalavakunta ${ }^{3}$
}

- Additional material is published online only. To view please visit the journal online (http://dx.doi.org/10.1136/ bcr-2018-225647).

${ }^{1}$ Internal Medicine, Western Michigan University School of Medicine, Kalamazoo, Michigan, USA

${ }^{2}$ Internal Medicine and Pediatrics, Western Michigan University Homer Stryker School of Medicine, Kalamazoo, Michigan, USA

${ }^{3}$ Borgess Medical Center, Michigan State University, Kalamazoo, Michigan, USA

\section{Correspondence to} Dr Dominika M Zoltowska dominika.zoltowska@med. wmich.edu

Accepted 29 May 2018

\section{DESCRIPTION}

A 39-year-old morbidly obese man with a medical history of tobacco abuse and paroxysmal atrial fibrillation (Afib) on rivaroxaban presented to the emergency department with acute onset of shortness of breath and severe pleuritic chest pain. His vital signs were significant for blood pressure of $100 / 60 \mathrm{~mm} \mathrm{Hg}$, heart rate of 110 per minute, respiratory rate of 30 per minute and oxygen saturation of $80 \%$ on a non-rebreather mask. Physical examination was unremarkable, except for increased work of breathing. Arterial blood gas (ABG) showed $\mathrm{pH}$ 7.49, $\mathrm{Pa}_{\mathrm{CO} 2} 30 \mathrm{~mm} \mathrm{Hg}$ and $\mathrm{Pa}_{\mathrm{O} 2} 86 \mathrm{~mm} \mathrm{Hg}$. Laboratory tests were significant for elevated troponin at $2.35 \mathrm{ng} / \mathrm{mL}$ and B-type natriuretic peptide at $309 \mathrm{pg} /$ $\mathrm{mL}$. ECG showed sinus tachycardia with new onset incomplete right bundle block and T-wave inversion in the right precordial and the inferior leads (figure 1A). A chest CT revealed extensive bilateral pulmonary embolism (PE), involving both main pulmonary arteries and suspected mass in the right atrium (RA). Subsequent transoesophageal echocardiogram showed markedly dilated RA, right ventricle (RV) and pulmonary artery, along with severely reduced RV systolic function, and a massive, $10 \mathrm{~cm}$ thrombus traversing both atria via abnormal interatrial communication, occupying the left atrial appendage (LAA) and protruding into the left ventricle (figure $1 \mathrm{~B}$, video 1 ). Lower extremity Doppler ultrasound was consistent with acute occlusive deep venous thrombosis (DVT) in the right femoral and popliteal vein. The patient was started on heparin drip and transferred to intensive care unit. A multidisciplinary decision was made to proceed with emergent sternotomy with a removal of intracardiac thrombus and closure of the abnormal interatrial communication, which was intraoperatively recognised as an ostium secundum atrial septal defect, LAA occlusion (50 mm ArtiClip) and pulmonary artery thromboembolectomy along

Check for updates

To cite: Zoltowska DM, Agrawal Y, Gupta V, et al. BM Case Rep Published Online First: [please include Day Month Year]. doi:10.1136/ bcr-2018-225647

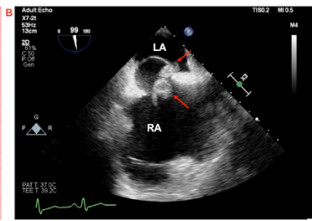

Figure 1 (A) ECG showing sinus tachycardia and right ventricle strain pattern. (B) Transoesophageal echocardiogram. Red arrows pointing thrombus traversing both atria via abnormal interatrial communication. LA, left atrium; RA, right atrium.

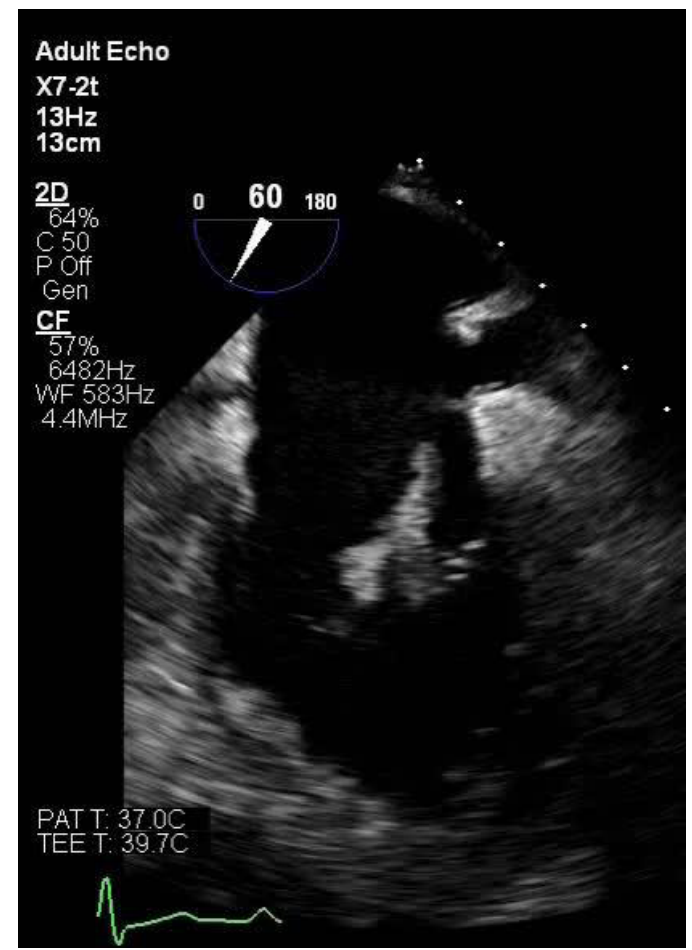

1 Transoesophageal echocardiogram showing large thrombus in the left atrium.

with a temporal inferior vena cava filter placement. All procedures were performed without complications. At the 2-month follow-up visit, the patient showed expected level of convalescence.

Atrial septal defect (ASD) is one of the most common congenital heart diseases, which can present at any age, most commonly with the symptoms of right heart failure. Concomitant Afib is a common comorbidity. Transthoracic echocardiogram is a reasonable first-line modality in evaluation of atrial septum. ${ }^{1}$ American Heart Association 2008 guidelines recommend ASD closure predominantly in the context of RA and RV enlargement (class I), as well as in the presence of paradoxical embolisation or documented platypnoea-orthodeoxia syndrome (class IIa). ${ }^{2}$

A venous thrombus entrapment within an abnormal interatrial communication is a rare initial manifestation of ASD and a clinical emergency due to the risk of impending systemic embolisation. ${ }^{3}$ The risk is especially deemed high in the context of acute massive pulmonary embolism causing transient RA pressure elevation and consequent shunt direction reversal, from left to right into right to 
left, promoting paradoxical embolisation. As this circumstance is rarely documented, most clinical experience regarding the optimal treatment has been incorporated from patent foramen ovale (PFO) studies. Our patient underwent urgent surgical treatment, including simultaneous thromboembolectomy, ASD closure and LAA occlusion. This approach enabled effective treatment of the patient's acute condition, along with prevention of both paradoxical and cardiac embolisation attributed to Afib. Concurrently, the patient required anticoagulation for secondary prevention of DVT/PE. Rivaroxaban was switched to warfarin.

\section{Learning points}

- Thrombus in transit as the rare initial manifestation of atrial septal defect (ASD).

- Dual risk of systemic embolisation in patient with ASD.

- The importance of timed diagnosis with echocardiography and the need for an interdisciplinary approach to manage further treatment of the trapped thrombus in ASD.

Contributors DMZ, YA, VG and JKK were the physicians in charge of the patient throughout hospitalisation and follow-up. They were responsible for performing, diagnosing and discussing the imaging studies of the patient. DMZ prepared the manuscript draft, which was critically revised by VG and JKK, and approved by all authors.

Funding The authors have not declared a specific grant for this research from any funding agency in the public, commercial or not-for-profit sectors.

Competing interests None declared.

Patient consent Obtained.

Provenance and peer review Not commissioned; externally peer reviewed.

(c) BMJ Publishing Group Ltd (unless otherwise stated in the text of the article) 2018. All rights reserved. No commercial use is permitted unless otherwise expressly granted.

\section{REFERENCES}

1 Silvestry FE, Cohen MS, Armsby LB, et al. Guidelines for the echocardiographic assessment of atrial septal defect and patent foramen ovale: from the American Society of Echocardiography and Society for Cardiac Angiography and Interventions. J Am Soc Echocardiogr 2015;28:910-58.

2 Warnes CA, Williams RG, Bashore TM, et al. ACC/AHA 2008 guidelines for the management of adults with congenital heart disease: executive summary: a report of the American College of Cardiology American Heart Association Task Force on Practice Guidelines (Writing Committee to Develop Guidelines for the Management of Adults with Congenital Heart Disease). Circulation 2008;118:2395-451.

3 Zoltowska DM, Agrawal Y, Kalavakunta JK. Serpentine thrombus in the heart: a rare case of trapped thrombus in patent foramen ovale. BMJ Case Rep 2018.

Copyright 2018 BMJ Publishing Group. All rights reserved. For permission to reuse any of this content visit http://group.bmj.com/group/rights-licensing/permissions.

BMJ Case Report Fellows may re-use this article for personal use and teaching without any further permission.

Become a Fellow of BMJ Case Reports today and you can:

- Submit as many cases as you like

- Enjoy fast sympathetic peer review and rapid publication of accepted articles

- Access all the published articles

- Re-use any of the published material for personal use and teaching without further permission

For information on Institutional Fellowships contact consortiasales@bmjgroup.com

Visit casereports.bmj.com for more articles like this and to become a Fellow 